\title{
Research Article: Constraints faced and suggestions given by households in adoption of KVK intervention
}

\author{
$\square$ Kadli Veeresh and S.B. Hosmani
}

Article Chronicle: Received : 25.11.2017;

Revised : 22.03.2018;

Accepted :

07.04.2018

KeY Words : KVK, Adoption, Constraints

Author for correspondence :

Kadli Veeresh

Department of Agricultural Economics, College of Agriculture, University of Agricultural Sciences, Dharwad (Karnataka) India

Email:kadliveeresh@ gmail.com

See end of the article for authors' affiliations
SUMMARY : Krishi Vigyan Kendras (KVKs) in India have been established by ICAR to cater the needs of the farming communities. Krishi Vigyan Kendra is an innovative science based institution which undertakes vocational training to farmers, farmwomen and rural youth. The overall objective of KVKs is technology assessment, refinement and demonstration for developing location specific technology modules in agriculture and allied enterprises. To ascertain the objectives of KVK the mandates are conducting on-farm testing and frontline demonstrations, organizing trainings for farmers and extension personnel and KVKs act as resource and knowledge centre of agricultural technology for supporting initiatives of public, private and voluntary sector for improving the agricultural economy of the district. The KVK, Saidapur managed by the University of Agricultural Sciences (UAS), Dharwad was purposively selected for the study.Purposive sampling technique was adopted for the selection of the district, and farmers. Three important income and employment generating training programmes (interventions) viz., vermicompost, seed production and household enterprise (vermicelli) were selected. In each intervention, 40 respondents were randomly selected making a sample of 120 . The study was based on both secondary and primary data. Garrett ranking technique was used for analysis of the data. In adoption of vermicompost intervention, majority of the respondents expressed financial problem, rate of interest and difficult to obtain subsidy. In adoption of soyabean seed production intervention, majority of the respondents expressed high cost of fertilizer as the major constraint followed by low price of the produce and storage facilities. In adoption of vermicelli production intervention, majority of the respondents expressed lack of availability of loan and high cost of machines. Suggestions given by households in adoption of KVK intervention are easy availability of subsidy, reduce the rate of interest and provide storage facility.

How to cite this article : Veeresh, Kadli and Hosmani, S.B. (2018). Constraints faced and suggestions given by households in adoption of KVK intervention. Agric. Update, 13(2): 164-168; DOI : 10.15740/HAS/AU/13.2/ 164-168. Copyright@2018: Hind Agri-Horticultural Society. 